Abstracta Iranica Abstranica

Revue bibliographique pour le domaine irano-aryen

Volume 25 | 2004

Comptes rendus des publications de 2002

\title{
Treasures of Ancient Bactria. Japon, Miho Museum, 2002, 253 p., texte trilingue (japonais, anglais et français).
}

\section{Ètsuko Kageyama}

\section{OpenEdition}

1 Journals

\section{Édition électronique}

URL : http://journals.openedition.org/abstractairanica/4202

DOI : 10.4000/abstractairanica.4202

ISSN : 1961-960X

Éditeur :

CNRS (UMR 7528 Mondes iraniens et indiens), Éditions de l'IFRI

\section{Édition imprimée}

Date de publication : 15 mai 2004

ISSN : 0240-8910

\section{Référence électronique}

Ėtsuko Kageyama, "Treasures of Ancient Bactria. Japon, Miho Museum, 2002, 253 p., texte trilingue (japonais, anglais et français). », Abstracta Iranica [En ligne], Volume 25 | 2004, document 52, mis en ligne le 15 mars 2006, consulté le 25 septembre 2020. URL : http://journals.openedition.org/ abstractairanica/4202 ; DOI : https://doi.org/10.4000/abstractairanica.4202

Ce document a été généré automatiquement le 25 septembre 2020.

Tous droits réservés 


\title{
Treasures of Ancient Bactria. Japon, Miho Museum, 2002, 253 p., texte trilingue (japonais, anglais et français).
}

\author{
Ètsuko Kageyama
}

1 Catalogue d'une exposition organisée par le Musée Miho au Japon, du 20 juillet au 15 décembre 2002, dans lequel est publiée pour la première fois la collection du «Trésor de la Bactriane » que renferme le musée : des monnaies, des figurines, des plaques d'exvotos, des armes miniatures, de la vaisselle, des accessoires, etc., dont la plupart sont d'or ou d'argent. Le catalogue est complété par des articles d'A. Green sur cette collection et sur les plaques d'ex-votos, et d'O. Bopearachchi sur les monnaies.

2 I. R. Pichikyan, qui a examiné une partie du « Trésor de la Bactriane », a considéré qu'il avait fait corps avec le « Trésor de l'Oxus » du British Museum (VDI 1998/1, 2). A. Green est réservé sur le problème de la provenance de la collection du musée Miho, mais il s'agit probablement d'éléments du trésor de Mir Zakah II (F. Grenet, dans Annuaire É cole Pratique des Hautes Études 111 (2002-2003), d'après des témoins oculaires).

\section{INDEX}

Thèmes : 3.1. Est de l'Iran 
AUTEURS

ÈTSUKO KAGEYAMA

CNRS - Paris 